\title{
JUURNAL_RU
}

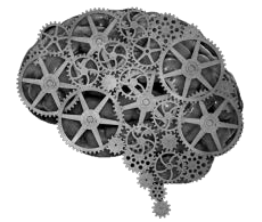

COMPANY GROUP "INTELLEKT"

Конвисарова Л. А. Костанайский государственный педагогический институт Костанай, Казахстан

doi: 10.18411//j2016-9-1-07

idsp 000001: lj2016-18-1-07

\section{Дидактические основы преподавания этнориторики}

С распадом СССР у отдельных суверенных государств появилась необходимость поиска путей и средств межнациональных отношений и коммуникации как внутри страны, так и за ее пределами.

Одним из таких путей, на наш взгляд, является формирование у подрастающего поколения поликультурного сознания, которая включает в себя следующие компоненты: знание истории, культуры этноса, с которой осуществляется процесс общения, знание роли своей национальной культуры и роли культуры этноса-партнера в мировой культуре; знание особенностей национальной культуры как выражения национальной психологии; эмпатия означающая знание психологических особенностей этноса, способности к сопереживанию, умение поставить себя на место другого.

Успешное формирование культуры межнационального общения у подрастающего поколения в образовательных учреждениях возможно только тогда, когда педагог сам свободен от негативных национальных стереотипов и предрассудков, владеет этнопедагогическими и этнопсихологическими знаниями, умениями корректировать содержание образования с учетом этнического многообразия нашей страны.

Цель поликультурного образования состоит в формировании человека, способного к активной и эффективной жизнедеятельности в многонациональной и поликультурной среде, обладающего развитым чувством понимания и уважения других культур, умения жить в мире и согласии с людьми разных национальностей, рас, верований. Поэтому мы полагаем, что формирование этно- 
культурологической компетентности и воспитание этнокультурных отношений является важнейшей стратегической задачей образования в XXI веке.

Педагогическое этнокультурное наследие, содержащее веками апробированные средства гармоничного существования человека в социуме, природе, при условии методологически грамотного и методически выверенного включения в универсальное культурное пространство становится в наше время способом интеграции личности в мировое целое.

В контексте такого подхода к образованию как к важному фактору сохранения народности, наиболее актуальной задачей теории образования на сегодня является разработка национальной модели образования. При этом очень важно, чтобы национальная модель образования, включала в себя сведения о своеобразии национальной культуры и воспитательные компоненты, которые необходимо внести в содержание образования.

Народную педагогику можно было бы в общем и целом представить как историю и теорию народного (естественного, обыденного, неформального, нешкольного, традиционного) воспитания. Этнопедагогика объясняет народную педагогику и предлагает пути ее использования в современных условиях, собирает и исследует опыт этнических групп, основанный на многовековом, естественно развивающимся соединении народных традиций. Она изучает процесс социального взаимодействия и общественного воздействия, в ходе которого воспитывается, развивается личность, усваиваются социальные нормы, ценности, опыт.

Преемственность поколений обеспечивается воспитанием, которое выступает как фактор социального развития личности и духовного прогресса народа.

Современная педагогическая наука придает все большее значение исследованию проблем истории и теории этнопедагогики, изучение которой невозможно без осознания и осмысления того фактора, что каждая нация имеет свои особенности, характерные свойства, нравственные нормы, обычаи, обряды, образы жизни. У каждого народа сотни лет существует особенная, укоренившаяся в жизни культура, которая неизбежно оказывает воздействие на воспитательный процесс. Проблемы влияния национальной культуры на воспитание подрастающего поколения нашли освещение в многочисленных 
работах педагогов советского периода, чьи заслуги в деле становления образования трудно переоценить.

Народное языковое воспитание должно быть привито подрастающему поколению. Обучение этнориторике может стать эффективным средством формирования всесторонне развитой личности. Достичь этой цели возможно лишь в случае, если в основе обучения будут учтены дидактические закономерности и принципы.

Под принципами обучения понимаются исходные положения, которые, действуя во взаимосвязи и взаимообусловленности, определяют содержание, методы и организацию обучения.

История дидактики характеризуется настойчивым стремлением исследователей выявить общие принципы обучения и на их основе сформулировать те важнейшие требования, соблюдая которые обучающиеся могли бы достичь высоких и прочных результатов.

В современной дидактике принципы обучения рассматриваются как «...определенная система исходных, основных дидактических требований к процессу обучения, выполнение которых обеспечивает его необходимую эффективность» $[1,161]$.

Принципы дают преподавателю понимание общей картины объективного развития процесса обучения. По мнению И.П.Подласого, «дидактические принципы - это основные положения, определяющие содержание, организационные формы и методы учебного процесса в соответствии с его общими целями и закономерностями» [2, 440].

Методика преподавания этнориторики основывается как на общедидактических принципах обучения (научности, наглядности, сознательности и активности, прочности знаний, системности, последовательности, доступности, индивидуальности, связи с жизнью, связи теории с практикой), так и на принципах повышения интереса, импровизации, реакции на ситуацию, учета аудитории, народности.

Повышение интереса происходит через интерес к теме и предмету, через интерес к личности оратора, через интерес к его творчеству. Для формирования познавательного интереса к предмету необходимо знать факторы и условия их формирования. На основе познавательного интереса приобретает особенно 
важное значение формирование у студентов обобщенных познавательных умений (умения наблюдать, систематизировать и обобщать знания, объяснять).

Пидкасистый П.И. добавляет и уточняет такие принципы обучения, как принцип развивающего и воспитывающего характера обучения и принцип прочности рационального сочетания коллективных и индивидуальных форм. Раскрывая принцип развивающего и воспитывающего характера обучения, автор подчеркивает, что обучение должно быть направлено не только на формирование знаний и умений, но и на цели всестороннего развития личности, привития определенных нравственных и эстетических качеств, которые служат основой выбора жизненных идеалов и социального поведения. Кроме того, исследователь видит осуществление данного принципа в разнообразных видах деятельности учащихся внеаудиторных занятий. Анализ предложенной системы принципов обучения по П.И.Пидкасистому позволяет сделать вывод о том, что только в совокупности использования предложенных принципов обучения в организации учебного процесса можно добиться решения задач обучения и воспитания.

Принцип народности, научно обоснованный К.Д.Ушинским [3], как принцип национального воспитания в условиях демократизации общества приобретает необычайную актуальность [4]. У каждого народа есть национальные святыни, очаги культуры, где сохранились традиции, в которых выкристаллизовался его коллективный опыт воспитания новых поколений. В народной педагогике выделяется традиция, ориентированная на память рода, знание своих истоков, корней, легенд, связанных с добрыми делами своих предков.

В современной дидактике принципы обучения рассматриваются как рекомендации, направляющие педагогическую деятельность и учебный процесс в целом, как способы достижения педагогических целей с учетом закономерностей учебного процесса. В принципах обучения проявляются философские, социальные, психологические, естественнонаучные закономерности.

В последнее время высказываются идеи о выделении группы принципов обучения в высшей школе, которые бы синтезировали все существующие принципы: 
- ориентированность высшего образования на развитие личности будущего специалиста;

- соответствие содержания вузовского образования современным и прогнозируемым тенденциям развития науки (техники) и производства (технологий);

- оптимальное сочетание общих, групповых и индивидуальных форм организации учебного процесса в вузе;

- рациональное применение современных методов и средств обучения на различных этапах подготовки специалистов;

- соответствие результатов подготовки специалистов требованиям, которые предъявляются конкретной сферой их профессиональной деятельности, обеспечение их конкурентоспособности.

Среди казахстанских исследователей проблем вузовской дидактики считаем необходимым анализ системы принципов обучения З.К.Жантекеевой. Автор, совместно с другими учеными, считает, что «принципы обучения - это система важнейших дидактических требований, соблюдая которые можно обеспечить эффективное функционирование учебного процесса» $[5,67]$.

При отборе принципов обучения в высшей школе приоритетным авторы считают принцип сочетания различных методов обучения. Характеризуя данный принцип, исследователи обращают внимание на то, что эффективность обучения закономерно зависит от выбора методов преподавания, стимулирования и контроля. При этом выбор методов и средств обучения должен соответствовать поставленным задачам, учитывать особенности содержания и возможности обучаемых, что в конечном итоге определит достижение поставленной цели.

Этому принципу придавал большое значение Ю.К.Бабанский. В основе принципа сочетания различных методов и средств обучения он видел, в первую очередь, хорошее знание преподавателем различных методов и средств обучения, обеспечение выбора наиболее приемлемых в соответствующих условиях.

Организация образовательного процесса протекает тем успешнее, чем у большего количества обучаемых удалось возбудить и развить познавательный интерес. Не случайно проблема познавательного интереса привлекала внимание таких педагогов, как Я.А.Коменский, К.Д.Ушинский, А.Дистервег. Интерес 
является одним из важнейших стимулов к учению, познанию нового. Под его влиянием развивается интеллектуальная активность, совершенствуется память, обостряется работа воображения, восприятия, повышается внимание, сосредоточенность [6].

При формировании интереса учащихся к этнориторике также необходимо учитывать аудиторию, ее возрастные особенности.

Учебный процесс оказывает воспитывающее и развивающее влияние. Воспитывающий характер обучения включает несколько направлений:

- связь содержания материала с общественно-политической жизнью страны, с современной наукой и культурой;

- управление процессом формирования чувств, впечатлений, которые возникают в учебном процессе;

- воспитание нравственных качеств личности, дисциплинированности, упорства, трудолюбия;

- развитие и формирование умственных способностей.

Таким образом, к воспитательным задачам вузовских занятий по этнориторике и культуре речи можно отнести: нравственное воспитание, воспитание познавательной самостоятельности, воспитание личностных качеств посредством индивидуальных интересов и способностей, патриотизма, любви к слову, а также личным примером.

Важнейшее открытие второй половины XX века - это внедрение в практику принципа воспитания успехом. Суть его в том, что педагог, работая со студентом, стремится как можно глубже понять его, осмыслить его особенности, опираясь на его достоинства, ценности, мечты, потребности, развивать малые ростки успеха. Для этого необходимо увлеченность педагога своей работой, высокий профессионализм, способность к эмпатии (сопереживанию) и рефлексии, умение создавать среду возможной успешности, когда каждый студент сможет почувствовать и испытать вкус победы.

Личностно-ориентированный подход к обучению, подготовка всесторонне развитой личности, учет индивидуальных особенностей обучаемых возможны только при соблюдении каждого принципа и всей системы активных методов (например, ролевых, риторических игр, диспутов) как воплощение современной концепции становления и развития риторической личности. 
На основании представленных систем педагогических принципов можно сделать вывод, что при различных подходах к их определению они должны сохранять специфичность, то есть отражать особый характер связей именно внутри дидактической системы. Это внутреннее единство предполагает:

- учет уровня подготовленности, возрастных и индивидуальных возможностей и особенностей студентов;

- создание положительного эмоционального климата и мотивов изучения;

- единство конкретного и абстрактного, рационального и эмоционального как выражение комплексного подхода;

- активность и самостоятельность студентов в учебной работе;

- основательность и прочность усвоения ключевых элементов, логики, практических навыков и умений;

- рациональное сочетание коллективных и индивидуальных форм и способов учебной работы, обеспечивающих развитие личности.

Таким образом, содержание риторического образования в вузе должно включать те материалы, которые дают возможность воспитывать у молодежи национальные чувства и национальную гордость.

Реалии настоящего времени все активнее требуют от вуза выполнения социального заказа на подготовку выпускников, обладающих широкой риторической компетенцией, которая является необходимым условием для дальнейшего профессионального становления. Умение владеть приемами и средствами эффективной коммуникации, навыки работы с текстами и другими источниками информации, которые развивает курс этнориторики, необходимы для множества видов деятельности. 


\section{Литература:}

1. Бабанский К.Ю. Педагогика. - М.: Высшая школа, 1983, 608 с.

2. Подласый И.П. Педагогика. Новый курс в 2-х книгах. Общие основы. Процесс обучения. - М.: Высшая школа, 1999.

3. Ушинский К.Д. Проблемы русской школы. Избр. пед. соч. - М.: Педагогика, 1974, Т.2.

4. Желдыбаева Б.С. Организация познавательной деятельности учащихся на основе этнопедагогики - залог разностороннего развития их личности // Вестник Томского государственного педагогического университета. Выпуск 3(77), 2008, С.8-11.

5. Бабанский К.Ю., Ильина Т.А., Жантекеева З.У. Педагогика высшей школы. - Алматы: Алматы кітап баспасы, 1989, 176 с.

6. Маусымбаев С.С., Желдыбаева Б.С. Организация познавательной деятельности учащихся на основе этнопедагогики // Педагог: наука, технология, практика. - Барнаул. - №1-2(22-23), 2007, С.81-85. 